\title{
Diagnostic Stability of Major Depressive Disorder in hospitalized patients in a University Hospital: a Brief Report
}

\author{
Estabilidad diagnóstica del trastorno de depresión mayor en pacientes \\ hospitalizados en el Departamento de Psiquiatría de un Hospital Universitario: \\ un breve informe
}

\author{
Enrique De Doménico $\mathbb{B}^{1}$, João Mauricio Castaldelli-Maia $\mathbb{B}^{2,3}$, Antonio Ventriglio $\mathbb{B}^{4}$, Julio Torales $\mathbb{B}^{1,5}$
}

${ }^{1}$ Universidad Nacional de Asunción, Departamento de Psiquiatría, San Lorenzo, Paraguay.

${ }^{2}$ Fundação do ABC, Medical School, Department of Neuroscience, Santo André, SP, Brazil.

3University of São Paulo, Medical School, Department of Psychiatry, São Paulo, SP, Brazil.

${ }^{4}$ University of Foggia, Department of Clinical and Experimental Medicine, Foggia, Italy.

5Universidad Nacional de Asunción, Departamento de Psicología médica, San Lorenzo, Paraguay.

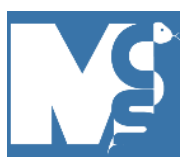

Received: $11 / 07 / 2021$

Revised: $15 / 08 / 2021$

Accepted: 22/08/2021

\section{Corresponding author}

\section{Julio Torales}

National University of Asunción

San Lorenzo - Paraguay

jtorales@med.una.py

\section{Conflicts of interests}

The authors declare that there is no conflict of interest.

\section{Funding}

The authors received no financial support for the research, authorship, and/or publication of this article.

This article is published under Creative Commons Attribution 4.0 International License.

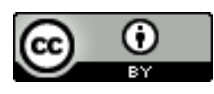

\section{ABSTRACT}

Introduction: There may be a discordance between diagnoses at admission and discharge of mentally ill patients with major issues regarding their diagnostic stability. The objective of this brief report was to determine the diagnostic stability of major depressive disorder at patients' discharge and if the diagnosis of their hospital admission had been retained. Methodology: This was a pilot, descriptive, cross-sectional, and retrospective observational study. A non-probabilistic sampling of consecutive cases was used. We reviewed the medical records, at admission and discharge, of patients with an initial diagnosis of major depressive disorder, hospitalized in the Department of Psychiatry of the 'Hospital de Clínicas' of the National University of Asunción, Paraguay, during the months of October to December 2020. Results: Fifty-three patients with a diagnosis of major depression on their hospital admission were included in the study (mean age $=35.7 \pm$ 16.5 years). $79.2 \%$ were women, $52.8 \%$ were single, and $37.7 \%$ were from the Central province of Paraguay. The most frequent diagnosis at discharge was borderline personality disorder, in $35.8 \%$ of cases. Major depressive disorder was confirmed in $15.1 \%$ of cases. No significant relationship was found between any discharge diagnosis and sociodemographic data. Conclusion: The results of this study, although preliminary, described the trajectories of diagnoses in the Psychiatry Department of a University hospital, but confirmatory studies are needed.

Keywords: diagnosis; diagnostic stability; major depressive disorder; borderline personality disorder

\section{RESUMEN}

Introducción: puede existir una discordancia entre los diagnósticos al ingreso y al alta de los pacientes con enfermedades mentales, con problemas importantes en cuanto a su estabilidad diagnóstica. El objetivo de este breve informe fue determinar la estabilidad diagnóstica del trastorno depresivo mayor al alta de los pacientes y si se había mantenido el diagnóstico de su ingreso hospitalario. Metodología: se trata de un estudio observacional piloto, descriptivo, transversal y retrospectivo. Se utilizó un muestreo no probabilístico de casos consecutivos. Se revisaron las historias clínicas, al ingreso y al alta, de los pacientes con diagnóstico inicial de trastorno depresivo mayor, hospitalizados en el Departamento de Psiquiatría del Hospital de Clínicas de la Universidad Nacional de Asunción, Paraguay, durante los meses de octubre a diciembre de 2020. Resultados: se incluyeron en el estudio 53 pacientes con diagnóstico de depresión mayor a su ingreso hospitalario (edad media $=35,7 \pm 16,5$ años). El 79,2 \% eran mujeres, el 52,8 \% eran solteros y el $37,7 \%$ eran del Departamento Central del Paraguay. El diagnóstico más frecuente al alta fue el trastorno límite de la personalidad, en el $35,8 \%$ de los casos. El trastorno depresivo mayor se confirmó en el $15,1 \%$ de los casos. No se encontró relación significativa entre ningún diagnóstico al alta y los datos sociodemográficos. Conclusiones: los resultados de este estudio, aunque preliminares, describen las trayectorias de los diagnósticos en el Departamento de Psiquiatría de un hospital universitario, pero son necesarios estudios confirmatorios.

Palabras clave: diagnóstico; estabilidad diagnóstica; trastorno depresivo mayor; trastorno límite de la personalidad 


\section{INTRODUCTION}

Depression is a chronic illness that can affect thoughts, mood, and physical health. It is characterized by low mood, lack of energy, sadness, insomnia and inability to enjoy life (1). In Paraguay, the frequency of Depression in the Emergency Department of the 'Hospital de Clínicas' of the National University of Asunción is $16.75 \%$, so it may be considered a common illness (2). However, it is common that the diagnosis at admission may be not very accurate and during the hospitalization a more accurate psychiatric diagnosis is made (3-5).

There may be a discordance between diagnoses at admission and discharge of mentally ill patients with major issues regarding their diagnostic stability. Many factors may contribute to the diagnostic instability, such as the clinical criteria and clinical assessment of physician involved in the admission, as well as symptoms that may occur without the presence of disorder (3). The objective of this brief report was to determine the diagnostic stability of major depressive disorder at patients' discharge and if the diagnosis of their hospital admission had been retained.

\section{METHODOLOGY}

This was a pilot, descriptive, cross-sectional, and retrospective observational study. A non-probabilistic sampling of consecutive cases was used. We reviewed the medical records, at admission and discharge, of patients with an initial diagnosis of major depressive disorder, hospitalized in the Department of Psychiatry of the 'Hospital de Clínicas' of the Universidad Nacional de Asunción, during the months of October to December 2020. We reviewed information on the patient' sex (male, female), age, marital status (single, married, widower, divorced), and diagnosis at discharge (according to the 5th edition of the
Diagnostic and Statistical Manual of Mental Disorders, DSM-5) (6).

The sample size was calculated using the Epidat 4.2 epidemiological package (Pan American Health Organization, Galician Board of Health and the CES University of Colombia). Assuming a frequency of depression in the emergency department of $16.75 \%$ (2), a confidence interval of $95 \%$ and a precision of $10.5 \%$, the minimum sample was set at 49 patients. Finally, the sample included 53 patients (7).

Data were loaded into a spreadsheet and then processed with the PSPP statistical package. Categorical variables were summarized in the form of frequency tables, while quantitative variables were summarized with measures of central tendency and dispersion. The study was approved by the Department of Psychiatry of the National University of Asunción, School of Medical Sciences (Paraguay). Data were treated with confidentiality, equality, and justice, respecting the Helsinki principles.

\section{RESULTS}

Fifty-three patients with a diagnosis of major depression at their hospital admission were included in the study, with ages ranging from 13 to 73 years old (mean $=35.7 \pm 16.5$ years). $79.2 \%$ were women, 52.8 $\%$ were single, and $37.7 \%$ were from the Central province of Paraguay. Sociodemographic data can be seen in detail in Table 1. The most frequent discharge diagnosis was borderline personality disorder, in $35.8 \%$ of the cases. Major depressive disorder was confirmed in $15.1 \%$ of cases. Regarding the number of days of hospitalization, it ranged between 2 and 43 days (mean $=19 \pm 10$ days). Table 2 shows diagnoses at discharge. No significant relationship was found between any discharge diagnosis and sociodemographic data. Also, no significant difference was found between days of hospitalization and sociodemographic data.

TABLE 1. SOCIODEMOGRAPHIC DATA OF PARTICIPANTS ( $\mathrm{N}=53)$.

\begin{tabular}{lcc}
\hline Characteristic & $\mathbf{n}$ & $\%$ \\
\hline Gender & 11 & 20,8 \\
Male & 42 & 79,2 \\
Female & & \\
Civil status & 28 & 52,8 \\
Single & 141 & 26,4 \\
Married & 8 & 15,1 \\
Domestic partners & 3 & 5,7 \\
Divorced & & \\
Place of residence & 13 & 24,5 \\
Asunción city & 20 & 37,7 \\
Central province & 20 & 37,7 \\
Rest of the country & 20 &
\end{tabular}


TABLE 2. DIAGNOSIS OF PATIENTS AT THEIR DISCHARGE (N=53).

\begin{tabular}{lcc}
\hline \multicolumn{1}{c}{ Discharge diagnosis } & $\mathrm{n}$ & $\%$ \\
\hline Borderline personality disorder & 19 & 35,8 \\
Major depressive disorder (severe) & 8 & 15,1 \\
Major depressive disorder (partial remission) & 5 & 9,4 \\
Major depressive disorder (with psychotic features) & 4 & 7,5 \\
Posttraumatic stress disorder & 2 & 3,8 \\
Major depressive disorder (total remission) & 2 & 3,8 \\
Major depressive disorder (moderate) & 2 & 3,8 \\
Major depressive disorder (mild) & 2 & 3,8 \\
Adjustment disorder & 2 & 3,8 \\
Obsessive compulsive disorder & 1 & 1,9 \\
Dissociative amnesia & 1 & 1,9 \\
Generalized anxiety disorder & 1 & 1,9 \\
Narcissist personality disorder & 1 & 1,9 \\
Obsessive compulsive personality disorder & 1 & 1,9 \\
Dependent personality disorder & 1 & 1,9 \\
Alcohol use disorder & 1 & 1,9 \\
\hline
\end{tabular}

\section{DISCUSSION}

Depression is a disorder frequently reported in the emergency departments of psychiatric units, almost always accompanied by life-threatening behaviors that require immediate intervention and hospitalization (2). This research reported on the definitive diagnoses of patients who were classified at admission as affected by major depression. It is not uncommon in psychiatry that, as more is known about patient's clinical history and patient's biopsychosocial context, a different diagnosis from the initial one at admission may be made at discharge; this usually may happen for patients affected by bipolar disorder (8).

In this brief report, the most frequent definitive diagnosis was borderline personality disorder, in fact $35.8 \%$ of cases admitted as major depressions were rediagnosed as such at discharge. The overlap and convergence between these diagnoses has been discussed in the medical literature (9). The reactive depressive features and depressive symptoms, as integral parts of borderline personality disorder, may easily be misinterpreted and misdiagnosed as major depression (10).

Borderline personality disorder is a severe mental illness. People affected by this disorder present with intense dysregulation of emotions and impulses, an unstable sense of self and multiple difficulties in interpersonal relationships. In addition, the disorder is often accompanied by suicidal and self-injurious behaviors (11). Some authors have suggested that more than $60 \%$ of patients with borderline personality disorder received other different diagnoses as their first diagnosis. Stress-related disorders and depressive disorders were the most frequent first diagnoses. These low diagnostic stabilities demonstrate that patients with borderline personality disorder are a heterogeneous group of patients diagnosed with many other psychiatric diagnoses over time (12). This supports the need for prompt and accurate diagnosis.

Diagnostic stability is essential for the validation of mental disorders and serves as a basis for the prediction of their course and outcome (13). However, there are several factors that lead to the re-diagnosis of patients initially diagnosed with major depressive disorder. This highlights the need for a longitudinally based diagnostic process in the diagnostic systems.

For example, patients with bipolar disorder often receive the initial diagnosis of major depressive disorder, since patients often have one or more depressive episodes before their first manic or hypomanic syndrome (14). The likelihood of changing diagnosis is higher in patients with younger age of onset of their first lifetime major depressive episode, with family history of bipolar disorder, with psychotic symptoms or subthreshold hypomanic symptoms during the depressive episode, treatment resistance, and comorbid symptoms of attention deficit hyperactivity disorder or substance use disorders $(15,16)$. In the case of psychotic disorders, some studies have suggested that up to 30 percent of patients initially diagnosed with major depressive disorder eventually develop symptoms that warrant a change in diagnosis to a schizophrenia spectrum disorder $(17,18)$.

It is essential to make an accurate diagnosis in psychiatry, since this will allow establishing adequate and efficient treatments for each patient. Therefore, a good longitudinal follow-up of patients should always be carried out since many disorders may be defined on the base of their long-term outcome (e.g., bipolar 
disorder).

The results of this study, although preliminarily, let us to better understand the trajectories of diagnoses in the Psychiatry Department of a University hospital, even if confirmatory studies are needed.

Among limitations, it can be mentioned that the sample size is not optimal, since the error assumed in the calculation is greater than recommended. Another limitation is the type of sampling used (nonprobabilistic), which prevents the results from being generalized to the general population; however, internal validity is assured, so that the interpretations are valid, as long as they are applied to the present sample.

\section{AUTHOR'S CONTRIBUTIONS}

All the authors participated in the drafting, critical revision and final approval of the manuscript.

\section{REFERENCES}

1. Cui R. Editorial: A Systematic Review of Depression. Curr Neuropharmacol. 2015;13(4):480. https://doi.org/10.2174/1570159x1304150831123535

2. Torales J, Ventriglio A, Barrios I, Arce A. Demographic and clinical characteristics of patients referred to the psychiatry unit of the emergency department at the National University of Asunción's General Hospital, Paraguay. Int J Cult Ment Health. 2016;9(3):233-238. https://doi.org/10.1080/17542863.2016.1197290

3. Melgarejo OJ, Torales JC, Cantero JB. Código Z: necesidad de integrar un trabajador social psiquiátrico a la sala de internación del Servicio de Psiquiatría del Hospital de Clínicas. Un estudio piloto. An. Fac. Cien. Méd. (Asunción) 2017;50(3):29-40.

https://doi.org/10.18004/anales/2017.050(03)29-040

4. Sánchez R, Jaramillo LE, Quintero C. Estabilidad del Diagnóstico Psiquiátrico en Pacientes de Consulta Externa. Rev Colomb Psiquiatr. 2002;31(2):101-122. URL.

5. Kendell RE. The stability of psychiatric diagnosis. $\mathrm{Br} \mathrm{J}$ Psychiatry. 1974;124(0):352-356. https://doi.org/10.1192/bjp.124.4.352

6. American Psychiatric Association. Diagnostic and Statistical Manual of Mental Disorders. 5th ed. Arlington VA. APA Press, 2013.

7. Muñoz Navarro SR. ¿Cuántos sujetos necesito para mi estudio? [How many subjects do I need to power my study?]. Medwave. 2014;14(6):e5995. https://doi.org/10.5867/medwave.2014.06.5995

8. Cegla-Schvartzman FB, Ovejero S, López-Castroman J, BacaGarcía E. Diagnostic Stability in Bipolar Disorder: A Narrative Review. Harv Rev Psychiatry. 2019;27(1):3-14. https://doi.org/10.1097/HRP.0000000000000187

9. Paris J. Differential Diagnosis of Borderline Personality Disorder. Psychiatr Clin North Am. 2018;41(4):575-582. https://doi.org/10.1016/j.psc.2018.07.001

10. Rao S, Broadbear J. Borderline personality disorder and depressive disorder. Australas Psychiatry. 2019;27(6):573577. https://doi.org/10.1177/1039856219878643

11. Beatson JA, Rao S. Depression and borderline personality disorder. Med J Aust 2013; 199(6):S24-S27. https://doi.org/10.5694/mja12.10474
12. Kjær JN, Biskin R, Vestergaard C, Gustafsson LN, MunkJørgensen $P$. The clinical trajectory of patients with borderline personality disorder. Personality and Mental Health 2016;10:181-190. https://doi.org/10.1002/pmh.1337

13. Blázquez A, Ortiz AE, Castro-Fornieles J, Morer A, Baeza I, Martínez $E$, et al. Five-year diagnostic stability among adolescents in an inpatient psychiatric unit. Comprehensive Psychiatry 2019;89:33-39. https://doi.org/10.1016/j.comppsych.2018.11.011

14. Ratheesh A, Davey C, Hetrick S, Alvarez-Jimenez M, Voutier C, Bechdolf A, et al. A systematic review and metaanalysis of prospective transition from major depression to bipolar disorder. Acta Psychiatr Scand. 2017;135(4):273284. https://doi.org/10.1111/acps.12686

15. Chen MH, Chen YS, Hsu JW, Huang KL, Li CT, Lin WC, et al. Comorbidity of ADHD and subsequent bipolar disorder among adolescents and young adults with major depression: a nationwide longitudinal study. Bipolar Disord. 2015;17(3):315-322. https://doi.org/10.1111/bdi.12266

16. Bukh JD, Andersen PK, Kessing LV. Rates and predictors of remission, recurrence and conversion to bipolar disorder after the first lifetime episode of depression--a prospective 5-year follow-up study. Psychol Med. 2016;46(6):11511161. https://doi.org/10.1017/S0033291715002676

17. Kessing LV. Diagnostic stability in depressive disorder as according to ICD-10 in clinical practice. Psychopathology. 2005;38(1):32-37. https://doi.org/10.1159/000083968

18. Schwartz JE, Fennig S, Tanenberg-Karant M, Carlson G, Craig T, Galambos N, et al. Congruence of diagnoses 2 years after a first-admission diagnosis of psychosis. Arch Gen Psychiatry. 2000;57(6):593-600. https://doi.org/10.1001/archpsyc.57.6.593 